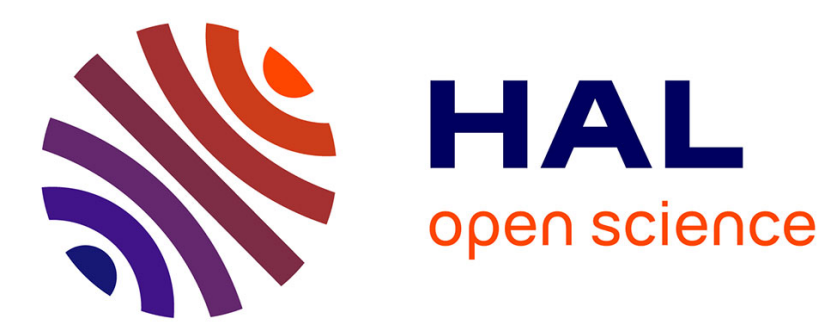

\title{
Risk of acquiring tick-borne infections in forestry workers from Lazio, Italy
}

S. Renzi, A. Martini, A. Binazzi, A. Marinaccio, N. Vonesch, W. d'Amico, T. Moro, C. Fiorentini, M. G. Ciufolini, P. Visca, et al.

\section{- To cite this version:}

S. Renzi, A. Martini, A. Binazzi, A. Marinaccio, N. Vonesch, et al.. Risk of acquiring tick-borne infections in forestry workers from Lazio, Italy. European Journal of Clinical Microbiology and Infectious Diseases, 2010, 29 (12), pp.1579-1581. 10.1007/s10096-010-1028-6 . hal-00615133

\section{HAL Id: hal-00615133 https://hal.science/hal-00615133}

Submitted on 18 Aug 2011

HAL is a multi-disciplinary open access archive for the deposit and dissemination of scientific research documents, whether they are published or not. The documents may come from teaching and research institutions in France or abroad, or from public or private research centers.
L'archive ouverte pluridisciplinaire HAL, est destinée au dépôt et à la diffusion de documents scientifiques de niveau recherche, publiés ou non, émanant des établissements d'enseignement et de recherche français ou étrangers, des laboratoires publics ou privés. 
1

2

3

4

\section{Risk of acquiring tick-borne infections in forestry workers from Lazio, Italy}

Simona Di Renzi ${ }^{1}$, Agnese Martini ${ }^{1}$, Alessandra Binazzi ${ }^{1}$, Alessandro Marinaccio ${ }^{1}$,

Nicoletta Vonesch ${ }^{1}$, Wanda D’Amico ${ }^{1}$, Tommaso Moro ${ }^{2}$, Cristiano Fiorentini ${ }^{3}$, Maria

Grazia Ciufolini ${ }^{3}$, Paolo Visca ${ }^{4}$, Paola Tomao ${ }^{1 凶}$

${ }^{1}$ Department of Occupational Medicine, Istituto Superiore per la Prevenzione e Sicurezza del Lavoro, 00040 Monte Porzio Catone, Rome, Italy;

${ }^{2}$ Immune-Haematological and Blood Transfusion Unit, Presidio Ospedaliero "San

Camillo de' Lellis", 02100 Rieti, Italy;

${ }^{3}$ Department of Infectious, Parasitic and Immune-Mediated Diseases, Istituto Superiore di Sanita, 00161 Rome, Italy;

${ }^{4}$ Department of Biology, University "Roma Tre", 00146, Rome, Italy.

\section{Corresponding author: paola.tomao@ispesl.it}

Phone: +390697896109

Fax: +390694181410 .

Key-words: occupational risk; forestry workers; Borrelia burgdorferi; Ixodes ricinus; TBE virus. 
Lyme borreliosis (LB) and tick-borne encephalitis (TBE) are tick-borne diseases that are transmitted in Europe by hard ticks, and pose growing health problems in rural areas.

LB is a multisystem, multistage, inflammatory disease resulting from infection by the spirochete Borrelia burgdorferi sensu lato (s.1.), which is transmitted by the tick Ixodes ricinus. It may cause skin, joint, neurological, ocular and cardiac disorders. Since forests and woods are the preferred ecosystem for maintenance of LB [1], the risk of contracting LB is greater in forestry workers, farmers, and other workers in wooded areas [2,3] which can acquire LB from infected ticks taking a blood meal.

TBE virus (TBEV, Flaviviridae family) infection is a biphasic febrile infection, often with neurological manifestations of meningo-encephalitis. The disease is prevalent in certain European areas and, like LB, transmitted by I. ricinus.

Sero-epidemiological studies suggest that LB and TBE infections are more prevalent among people exposed to tick bites, such as forestry workers [4].

To assess the occupational risk factors for tick-borne infections, the seroprevalence of antibodies to B. burgdorferi and TBEV was compared in 145 forestry rangers (exposed subjects) working in Central Italy and 282 blood donors (controls) from the same area (Lazio region; 17,227 $\mathrm{Km}^{2}$ with ca. $22 \%$ of wood; population 5,264,077 inhabitants). All 427 subjects were interviewed through a questionnaire and provided informed consent to the study (Supplementary text). All subjects were free of signs and symptoms of LB and TBEV infection. Both groups were age- and sex-modelled. Age was analyzed by ranking subjects in three groups with cut-off at the $33^{\text {rd }}$ percentile and no significant difference was found (Supplementary table 1).

Sera were collected in Summer 2008 and stored at $-80^{\circ} \mathrm{C}$ until used. Enzyme-linked immunosorbent assays (ELISA; recombWell Borrelia IgG and recombWell Borrelia IgM Arnika Diagnostics, Milan, IT; FSME IgG Immunozym, Progen Biotech GmbH, Heidelberg, DE) were used for the serological screening, followed by confirmatory Western blot analysis (WB; Borrelia "MIQ" Virablot Test kit IgG/IgM - Arnika Diagnostics; recomLine Borrelia IgM, Mikrogen, Neuried, DE) and haemagglutination inhibition (HI) [5] for B. burgdorferi and TBEV, respectively (Supplementary text). Since 
sera were taken during the period of highest tick activity, both IgM- and IgG -positive results were considered as markers of recent and past infection, respectively.

Tests for the TBE virus by ELISA showed 3 positive and 3 borderline samples (4.1\%), all among exposed forestry workers, but haemagglutination did not confirm any of the samples. This is in agreement with the known epidemiology of TBE in Italy, as no evidence of TBE circulation has so far been provided in Lazio region.

Among both the exposed subjects and controls, there were 14 positive and 6 borderline samples in the ELISA for IgG antibodies to B. burgdorferi s.1., while the IgM ELISA for B. burgdorferi s.l. showed 39 positive and 15 borderline samples (Table). Confirmatory WB was then performed for all positive or borderline $\operatorname{IgG}$ and IgM sera. Four subjects ( 1 exposed and 3 controls) were positive for IgG WB, and 42 (19 exposed and 23 controls) for IgM WB with the Borrelia "MIQ" Virablot Test (Arnika). Retesting of IgM-positive sera 20 months after sampling with the more restrictive recomLine Borrelia IgM assay (Mikrogen) confirmed seropositivity for only 28 subjects ( 9 exposed and 19 controls). This last result was confidently considered as true IgM-positive, and used for statistical analyses (Table). Overall, the WB-confirmed seropositivity for IgG and IgM was 10/145 (6.89\%) among exposed subjects and 22/282 (7.80\%) among controls. No sample tested WB-positive for both IgG and IgM.

A test for the difference between percentages of overall confirmed positive (IgG IgM WBs) in the exposed and control group was performed, but it was not statistically significant $(\mathrm{p}>0.1)$.

Significant differences were observed between indoor and outdoor, urban and rural workplaces among the 145 exposed subjects $\left(\chi^{2}\right.$ test: $\left.\mathrm{p}<0.001\right)$, and a higher risk for outdoor tasks performed in a rural rather than urban environment among the 10 positive exposed subjects $\left(\chi^{2}\right.$ test: $\left.p=0.075\right)$. A multivariate regression model applied to evaluate the explanatory variables for seroprevalence of antibodies against B. burgdorferi in the 145 exposed subjects (Supplementary text) showed a higher seroprevalence associated to rural work environment (OR: 1.74; 95\%CI: 0.25-11.86), lack of individual protective devices (OR: 2.45; 95\%CI: 0.37-16.08) and male sex (OR: 1.10; 95\%CI: 0.14-8.49), although none of these estimates reached the level of statistical significance $(\mathrm{p}>0.05)$. 
While a significantly higher prevalence of anti-B. burgdorferi antibodies in forestry workers than in the control group was not observed, the absence of significant associations with major risk factors among exposed subjects suggests a similar distribution of such risk factors among controls, without any difference between the two groups. Therefore the seroprevalence observed for the exposed group should be explained exclusively by occupational factors. In this group the analysis of specific jobs showed an increased risk for outdoor tasks performed in rural rather than urban environments.

The prevalence of these tick-borne zoonoses is probably underestimated because of poor surveillance of these diseases. In Italy the infectious diseases reporting system is not widely applied and there is no specific information for workers likely to be frequently exposed to ticks. However, serological surveys in healthy populations at risk of tick-borne diseases, such as LB and TBE, have reported significant proportions with antibodies reactive to microorganisms transmitted by infected Ixodes spp. ticks [6], and higher risk of occupational exposure to $B$. burgdorferi among people with outdoor activities $[4,7,8]$. The overall frequency of B. burgdorferi antibodies in forestry workers from this study is similar to that previously reported for another region in Central Italy [7], although IgM seroprevalence is higher (6.20\% vs. $3.64 \%$ in ref. [7]). Intriguingly, we observed a similar pattern of seropositivity also in the control group $(1.06 \%$ and $6.73 \%$ for $\operatorname{IgG}$ and $\operatorname{IgM}$, respectively), substantially differing from that reported by us in a previous survey of a neighbouring region (1.36\% and $2.46 \%$ for IgG and IgM, respectively) [7]. Nevertheless, the observed seropositivity appears to be 2 to 4 fold lower than that reported for Italian regions of LB endemicity [4]. Unfortunately, the lack of a second serum sample did not allow to verify seroconversion in IgM-positive subjects, and hence exclude false positives among those samples that resulted concordantly positive in both IgM WB assays.

We conclude that Lazio is a region of moderately high endemicity for LB. Therefore, the risk of acquiring LB should be considered for outdoor workers in this area, and prevention efforts will need to focus on behavioral intervention to reduce individual exposure by appropriate measures in outdoor environments. 


\section{ACKNOWLEDGEMENTS}

The authors would like to thank all the forestry workers of the Corpo Forestale

della Regione Lazio and blood donors who participated. We also thank the Immune-

Haematological and Blood Transfusion Unit of “San Camillo de' Lellis” Hospital (Rieti, Italy).

\section{FUNDING}

This study was supported in part by a grant from the Italian Ministry of Welfare. 


\section{REFERENCES}

1 Parola P, Raoult D (2001) Ticks and tick-borne bacterial diseases in humans: an emerging infectious threat. Clin Infect Dis 32:897-928.

2 Buczek A, Rudek A, Bartosik K, Szymańska J, Wójcik-Fatla A (2009) Seroepidemiological study of Lyme borreliosis among forestry workers in Southern Poland. Ann Agric Environ Med 16:257-261.

3 Cisak E, Chmielewska-Badora J, Rajtar B, Zwoliński J, Jabłonski L, Dutkiewicz J (2002) Study on the occurrence of Borrelia burgdorferi sensu lato and tick-borne encephalitis virus (TBEV) in ticks collected in Lublin region (eastern Poland). Ann Agric Environ Med 9:105-110.

4 Cinco M, Barbone F, Ciufolini MG, Mascioli M, Anguero Rosenfeld M, Stefanel P, Luzzati R (2004) Seroprevalence of tick-borne infections in forestry rangers from northeastern Italy. Clin Microbiol Infect 10:1056-1061.

5 Venturi G, Mel R, Marchi A, Mancuso S, Russino F, Da Pra G, Papa N, Bertiato G, Fiorentini C, Ciufolini MG (2006) Humoral immunity and correlation between ELISA, hemagglutination inhibition, and neutralization tests after vaccination against tick-borne encephalitis virus in children. J Virol Methods 134:136-9.

6 Piacentino JD, Schwartz BS (2002) Occupational risk of Lyme disease: an epidemiological review. Occup Environ Med 59:75-84.

7 Tomao P, Ciceroni L, D’Ovidio MC, De Rosa M., Vonesch N, Iavicoli S, Signorini S, Ciarrocchi S, Ciufolini MG, Fiorentini C, Papaleo B (2005) Prevalence and incidence of antibodies to Borrelia burgdorferi and to tick-borne encephalitis virus in agricultural and forestry workers from Tuscany, Italy. Eur J Clin Microbiol Infect Dis 24:457-463.

8 Santino I, Cammarata E, Franco S, Galdiero F, Oliva B, Sessa R, Cipriani P, Tempera G, Del Piano M (2004) Multicentric study of seroprevalence of Borrelia burgdorferi and Anaplasma phagocytophila in high-risk groups in regions of central and southern Italy. Int J Immunopathol Pharmacol 17:219-223. 
Table. Prevalence of antibodies against B. burgdorferi s.l. by IgG/IgM-Elisa in 145 exposed and 282 control subjects

\begin{tabular}{|c|c|c|c|c|c|c|}
\hline & \multicolumn{3}{|c|}{ IgG-Elisa } & \multicolumn{3}{|c|}{ IgM-Elisa } \\
\hline & Exposed (\%) & Controls (\%) & Total (\%) & $\begin{array}{c}\text { Exposed } \\
(\%)\end{array}$ & $\begin{array}{c}\text { Controls } \\
(\%)\end{array}$ & Total (\%) \\
\hline Positive & $5(3.4)$ & $9(3.2)$ & $14(3.3)$ & $19(13.1)$ & $20(7.1)$ & $39(9.1)$ \\
\hline Borderline & $4(2.8)$ & $2(0.7)$ & $6(1.4)$ & $7(4.8)$ & $8(2.8)$ & $15(3.5)$ \\
\hline $\begin{array}{r}\text { Confirmed } \\
\text { positive by WB1 } \\
W B 2^{a}\end{array}$ & $1(0.69)$ & $3(1.06)$ & $4(0.94)$ & $\begin{array}{r}19(13.10) \\
9(6.20)\end{array}$ & $\begin{array}{l}23(8.16) \\
19(6.73)\end{array}$ & $\begin{array}{l}42(9.84) \\
28(6.55)\end{array}$ \\
\hline Negative & $136(93.8)$ & $271(96.1)$ & 407 (95.3) & $119(82.1)$ & $254(90.1)$ & $373(87.4)$ \\
\hline Total & $145(100.0)$ & $282(100.0)$ & $427(100.0)$ & $145(100.0)$ & $282(100.0)$ & 427 (100.0) \\
\hline
\end{tabular}

${ }^{a}$ WB1 performed with the Borrelia "MIQ" Virablot Test (Arnika) on positive and borderline ELISA samples. WB2 retesting of IgM-positive sera was performed 20 months after sampling with the recomLine Borrelia IgM (Mikrogen) kit. 